\title{
Public organizational performance: Policy implementation in environmental management in Bandung City
}

\section{Kinerja organisasi publik: Implementasi kebijakan dalam pengelolaan lingkungan hidup di Kota Bandung}

\author{
Engkus* \& Ahmad Syamsir \\ Department of Public Administration, Faculty of Social and Political Sciences, \\ UIN Sunan Gunung Djati Bandung \\ Address: Jalan AH Nasution No. 105 Bandung, West Java, Indonesia 40614 \\ E-mail: engkus@uinsgd.ac.id
}

Artcile History: Received 14 August 2020; Accepted 18 October 2021; Published Online 29 November 2021

\begin{abstract}
This study is motivated by the performance of the Department of Environment and Hygiene Services of Bandung City which has not been optimal. This is partly due to the poor services in the underground water mining sector, thus it is a current synthesis. This study aims to explore and discuss organizational performance through policies that have been implemented. The research method used was a descriptive qualitative approach, using data collection techniques of observation, interviews, and literature study. The results of the study indicate that the performance of public organizations has not been optimal due to low responsibility, responsiveness, and accountability, as well as internal constraints that occur structurally, the competence of human resources and non-human resources that are not appropriate so that it affects performance in the underground water mining sector that does not comply rule. This study concludes that the organizational structure and human resources in public organizations have not been effective and efficient so that the completion of public services is hampered.
\end{abstract}

Keywords: environmental management; organizational performance; policy; resource

\begin{abstract}
Abstrak
Studi ini dilatarbelakangi oleh kinerja Dinas Lingkungan Hidup dan Kebersihan Kota Bandung yang belum optimal. Hal ini di antaranya disebabkan oleh lemahnya pelayanan di sektor pertambangan air bawah tanah, sehingga menjadi sintesis yang sering muncul saat ini. Tujuan studi ini adalah untuk menggali dan membahas kinerja organisasi melalui kebijakan yang telah diterapkan. Metode yang digunakan adalah pendekatan kualitatif deskriptif dengan menggunakan teknik pengumpulan data: observasi, wawancara, dan studi pustaka. Hasil studi menunjukkan bahwa kinerja organisasi publik belum optimal karena rendahnya tanggung jawab, sikap cepat tanggap, dan akuntabilitas, serta kendala internal yang terjadi secara struktural, kompetensi sumber daya manusia dan nonsumber daya manusia yang tidak sesuai sehingga berpengaruh terhadap kinerja di sektor pertambangan air bawah tanah yang tidak menaati aturan. Studi ini menyimpulkan bahwa struktur organisasi dan sumber daya manusia pada organisasi publik belum efektif dan efisien sehingga penyelesaian pelayanan publik menjadi terhambat.
\end{abstract}

Kata kunci: pengelolaan lingkungan hidup; kinerja organisasi; kebijakan; sumber daya

\section{Introduction}

Local government performance is an important indicator of progress towards the achievement of the organization's overall mission and can be viewed as an internal measure of community service efforts and achievements (Kelly \& Swindell 2002). Performance in its implementation is at least related to Law Number 9 of 2015 concerning Regional Government, Law Number 28 of 2009 concerning Regional Taxes and Levies, and Government Regulation of the Republic of Indonesia Number 18 of 2016 concerning Regional Apparatus.

This regional autonomy policy is a transfer of power from the center (central) to the regions (decentralization) based on the strength of the community (Suwaryo 2006). With the issuance of Government Regulation of 
the Republic of Indonesia Number 18 of 2016 concerning Regional Apparatus, the regional government immediately formed an organizational structure of work procedures.

Therefore, local governments are given the authority to form Regional Apparatus Organizations in accordance with the characteristics of the community and resources (HR and Natural Resources) based on participation, transparency, and accountability. As a follow-up to this policy, the Bandung City Government issued a policy in the form of Bandung City Regional Regulation Number 8 of 2016 concerning Formation and Arrangement of Bandung City Regional Apparatus and Mayor Regulation Number 1384 of 2016 concerning Position, Composition, Organization, Duties, and Functions as Well as Work Procedures Services.

Law Number 23 of 1997 concerning Basic Provisions for Environmental Management stated that the environment can be defined as a unitary space with all objects, forces, conditions, and living things, including humans and their behavior, which affect the survival and welfare of humans and other living creatures. The handling of environmental and mining emergencies as well as groundwater management is regulated through the delegation of part of the government's authority from the Mayor to the Head of the Environment and Hygiene Services and the Coordination Team for Licensing Control in the field of environmental management.

As a source of Regional Original Revenue, taxes from class $\mathrm{C}$ mining and groundwater need to be managed optimally in order to have a positive impact on increasing regional income. Based on observations, several negative impacts of class $\mathrm{C}$ excavation are unsustainable natural resources (renewable), topography, disturbed forest flora, pollution of rivers and springs (high mud content and company waste), damaged roads and other infrastructure at a low-quality level. Even worse, it does not rule out the possibility of disasters due to landslides (Muis et al. 2019).

To carry out its vision and mission, the Bandung City Environment and Hygiene Services requires resources in the form of human resources, facilities and infrastructure, and financing because it is disclosed that the resources available in the organization are one aspect that can determine the success of an organization in carrying out its main tasks and functions (Sumual 2017). However in reality, in carrying out their main tasks and functions, they still experience obstacles both in terms of resources and regulations (Akmaludin \& Yuniati 2019). One of the consequences of the above is the service of the underground water mining sector which has not been fully controlled. The number of good points in Bandung City is 1,109 well points, 885 licensed and 224/25.4\% unlicensed (DLHK Kota Bandung 2020).

Current groundwater problems are that (1) groundwater exploitation is increasingly intensive, unbalanced in the hydrological cycle, (2) various negative impacts of groundwater utilization: (a) lowering of groundwater level, (b) decrease in water quality, (c) seawater intrusion in coastal areas, (3) reduction of infiltration areas, increasing critical and damaged groundwater zones in several watersheds (Bandung, Bogor, and Bekasi), (4) the number of unlicensed good points, (5) imbalance between refill vs expenditure due to: (a) concentration of groundwater extraction in dense industrial areas, (b) groundwater theft, (c) the higher need for groundwater, and (d) changes in watershed functions, (6) lack of awareness of groundwater users in carrying out conservation, (7) surface water has not been able to play a role as the main source of clean water supply (Dinas ESDM Kota Bandung 2020).

Organizational performance appraisal is crucial because it can be seen as the level of achievement of the results that have been carried out (Ahyaruddin \& Akbar 2018). Lenvine in (Tangkilisan 2007) suggests three concepts to measure the performance of the public bureaucracy, including: responsibility, responsiveness, and accountability. This concept then becomes the theoretical basis for the discussion of this research. In addition, of course, the measurement of organizational performance is required as (Behn 2003) states that everyone measures performance. Managers in public organizations measure the performance of their organizations, contractors, and their collaboration with other parties. 
Previous similar research that is relevant to this research is on Reform of Groundwater Arrangement and Utilization at BPMPT of West Java Province (Case Study of Water Intake and Utilization in Bandung City) (Permana 2017). The similarity is that the research locus is in Bandung City with the object of research on mining problems in the groundwater sector and qualitative method as the approach. The difference is shown by the theories used in which the previous study used (Pollitt \& Bouckaert 2011) or reformed so that the purpose of controlling the use of groundwater is difficult to carry out effectively. Meanwhile, this study uses the theory of Lenvine in (Tangkilisan 2007).

Based on the problems and descriptions above, the study question which is also the research objective is "Is the performance of the public organizations of the Bandung City Environment and Hygiene Services based on responsibility, responsiveness, and accountability?"

\section{Research Method}

This research was conducted at the Department of Environment and Environment and Hygiene Services in Bandung City for the following reasons: first, the issue of groundwater often appears in the news and conversations of the public, making this topic interesting to investigate. Second, the research location in Bandung City makes it easy to conduct research and obtain data with the two Bandung Environment and Hygiene Services are newly formed services as part of the transfer of affairs to the Bandung City Regional Secretariat. Third, the researchers seek to know the performance of the new service in connection with the issuance of Bandung City Regional Regulation (PERDA) Number 8 of 2016 concerning the Formation and Structure of Bandung City Regional Apparatus as the implementation of Government Regulation Number 18 of 2016 concerning Regional Apparatus.

The method used in this research was a qualitative approach. Data collection techniques used were observation, interviews, and documentation studies. The observation technique was used to find out and observe the actual conditions in the field, both at the Department of Environment and Hygiene Services and the community related to mining, especially the underground water sector. The interview technique was used to obtain in-depth data from six informants, based on their adequacy and propriety as research subjects who can provide information about the phenomena/problems raised in qualitative research, which are divided into: (1) two key informants (Head of Environmental Management Agency and Head of Regional Revenue Service) as general and conceptual informants, (2) two main informants (Head of Environmental Management and Head of Section for Water, Soil, and Conservation Biodiversity) as informants who know in detail and are the "main actors" in technical operations, (3) two supporting informants (development partners/mining/water entrepreneurs, and the community) as informants who provide additional useful and relevant information and parties related to the main informants. Research documentation studies were used to explore research materials in the form of documentation and other materials available at the Department of Environment and Hygiene Services and in the community. Table 1 shows the research informants' data as follows:

Table 1.

Research informants

\begin{tabular}{lcc}
\hline \multicolumn{1}{c}{ Informant } & Initials & Total \\
\hline Head of Environmental Service & DUP & 1 \\
Regional Revenue Management Agency & APR & 1 \\
Head of Development, Supervision, and Control & LEN & 1 \\
Head of Environmental Development and Supervision Section & DAR & 1 \\
Mining partners and entrepreneurs (water) & ASH \& KAD & 2 \\
\hline Total & & 6 \\
\hline
\end{tabular}

Source: Primary data 
The literature study technique was used to obtain documents regarding the performance and organizational changes of regional apparatus. By reviewing documentation, the researchers intend to examine the realization of national development as outlined in the National Development Plan (NDP) at the regional implementation level.

Data analysis was carried out in three stages, including 1) data reduction, 2) data presentation, and 3) drawing conclusions/verification. (1) Data reduction is conducted through data collection both from the Department of Environment and Hygiene Services in Bandung City and the community through observation, interviews, and documentation/library studies. At this stage, the focus is on simplifying, abstracting, and transforming the raw data that emerges from the field. It means that at this stage the researchers sharpen, classify, direct, eliminate unnecessary data, and organize them. (2) Data presentation is conducted by collecting structured and relevant data and displaying them to make it easy to draw conclusions. (3) Drawing conclusions/verification is conducted through a discussion and interpretation to formulate research findings, novelties, conclusions, and contributions.

\section{Results and Discussion}

\section{Assessment indicators of organizational performance of the Bandung City environmental management service}

The discussion of this research refers to the theory of Lenvine in (Tangkilisan 2007) suggesting three concepts to measure the performance of public bureaucracy, including: (1) Responsibility, (2) Responsiveness, and (3) Accountability. The three measures, as the results of the study reveal, have been running, but have not fully met expectations. The researchers explain each point sequentially in the following paragraphs.

Responsibility. The organizational responsibility of the Bandung City Environment and Hygiene Services is seen from the implementation of the fifth mission, which is increasing the development of every business activity through environmental integration, with the aim of making business activities environmentally sound. The goal is to achieve the application of environmental management in every business activity. In order to achieve these aims and objectives, a policy on the use and development of environmentally friendly technology was adopted, with a program to develop economic activities that optimally utilize natural resources and have an environmental perspective. These activities promote environmentally-friendly technology for the community (Nugroho et al. 2019).

In addition, the activities carried out by the Bandung City Environment and Hygiene Services are the implementation of coaching and controlling group c mining material entrepreneurs with the aim of achieving administrative and technical order for mining entrepreneurs from class $\mathrm{c}$. They are conducted to increase public awareness including entrepreneurs/miners of their obligations. These findings are supported by a previous study (Astriani 2016), revealing that in decision-making, the best solution is the involvement and participation of mining partners in the field.

Based on this research, some groundwater entrepreneurs do not have a Regional Mining Permit (SIPD). This was also conveyed by the Head of Development, Supervision, and Control (LEN):

"The crucial problem faced by the Department of Environment and Hygiene Services of Bandung City today is the problem of illegal excavation carried out by the community. In handling it, we are not certain whether to close the business because there are considerations in finding solutions. We want all partners to be involved and participate in thinking about solutions so that the policies taken can be accepted by all."

Therefore, in making solutions to the mining sector, the involvement and participation of entrepreneurs/ miners are important to raise awareness and the best policies. From his statement, it is clear that the 
problem of illegal mining is one of the crucial problems faced by the Bandung City Environment and Hygiene Services, which in its completion requires firm handling. This is also reinforced by the statement of the Head of Environmental Development and Supervision Section (DAR) that:

"In dealing with the problem of illegal miners, it is like "simalakama fruit" for us because illegal miners are generally small people with low education and relatively little land and types of business. But according to regulations, it is required to meet the requirements of a relatively large number of businesses, which automatically requires thought and cost. Regional Mining Business Permits (SIPD) must prepare an Environmental Impact Analysis, Environmental Monitoring Efforts, and deposit reclamation costs in the form of savings to be used as collateral, and a savings book stored in the Department of Environment and Hygiene Services which can be recovered if the entrepreneur/miner have exploited and reclaimed ex-mining land".

From the above statement, it is clear that the entrepreneurs do not have the awareness to have a Regional Mining Permit. Based on observations and data, 27 businessmen/miners do not have a Regional Mining Permit and 23 entrepreneurs have a Regional Mining Permit. In addition, some companies use underground water that was not accompanied by a groundwater extraction permit. Of the 87 underground water user companies in Bandung City, 61 companies do not have underground water extraction permits and water meters, while only 26 companies have permits for using underground water.

In this regard, the researchers interviewed two supporting informants. First, the entrepreneur of "Gunung Djati Bandung" (ASH) said that "Our company complies with licensing regulations because it is in accordance with the demands of these regulations, and doing business commercially is something that must be met for business continuity and increase customer trust". Second, a resident who own drilled wells (KAD) said, "Until now I don't have a permit because my well was dug before the regulation came into effect, and many other residents do not have a permit".

The results of the interview can be understood from two sides. First, obeying the rules is driven by the level of awareness and understanding of the person himself. Second, the Bandung City Government, in this case, the Department of Environment and Hygiene Services, should continue to supervise, socialize, and enforce laws in the underground water sector mining sector so that entrepreneurs/communities are aware and understand that groundwater is important in relation to environmental benefits and sustainability for all and the future. For more details, see Table 2 below for the detailed data on regional mining permits.

Table 2.

Obedience of entrepreneurs/miners to rules

\begin{tabular}{lccc}
\hline \multirow{2}{*}{ Type of business } & \multicolumn{2}{c}{ SIPD/SIPA } & \multirow{2}{*}{ Total } \\
\cline { 2 - 3 } & Available & Unavailable & \\
\hline C group minerals & 23 & 27 & 50 \\
Underground water users & 26 & 61 & 87 \\
Industry & 50 & 51 & 101 \\
\hline Source: Bandung City Environmental & Management Agency, (processed by researchers)
\end{tabular}

With regard to the Table 2, many entrepreneurs do not have permits and do not comply with regulations. The Head of the Environmental Management Division said that to deal with underground water companies that do not yet have a Groundwater Intake Permit (SIPA), officers of Bandung City Environment and Hygiene Services continue to carry out various efforts by taking decisive action, closing companies that do not have permits, of course through some stages: Warning Letter I, Warning Letter 2, and Warning Letter 3.

However, based on the observations of the researchers, the activities carried out by the Department of Environment and Hygiene Services of Bandung City to achieve the mission and goals of the organization have not been maximized. This is evidenced by a large number of illegal miners, users of underground water services who do not have permits, and entrepreneurs who have not reported the 
results of environmental management and monitoring. Following are the Standard Operating Procedures (SOP) for Groundwater Concession Permits (SIPA):

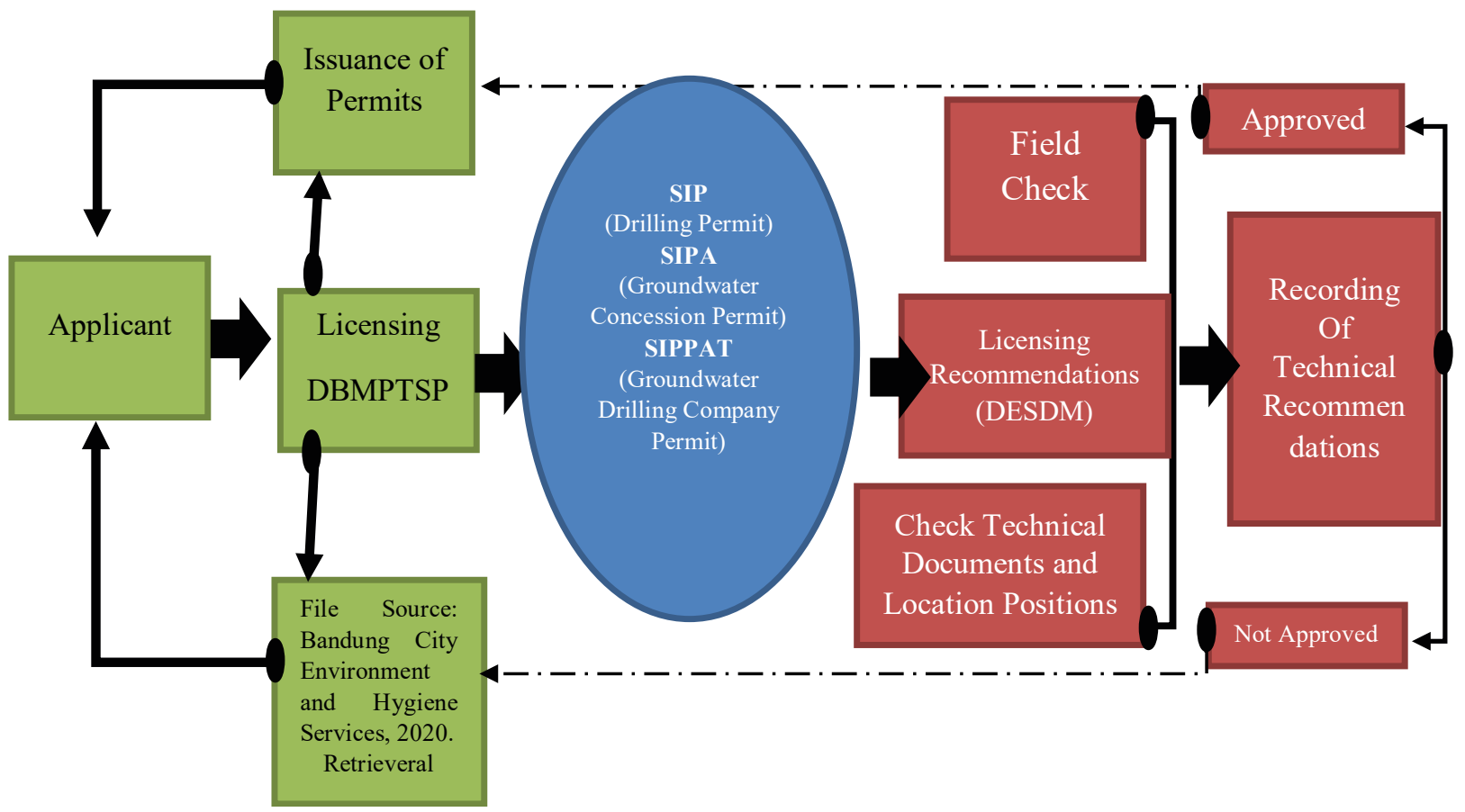

Figure 1.

Standard Operating Procedure (SOP) of groundwater concession permit (SIPA) Source: DLHK Kota Bandung (2020)

Figure 1. shows the stages as follows: (a) The applicant submits a written application with the requirements. (b) Front Office officers check the completeness and verify it; if it is incomplete and incorrect, the file is returned to the applicant to be completed. (c) The head of the service provides disposition for follow-up. (d) The head of the field checks the disposition sheet from the head of the service and forwards it to the head of the section. (e) The section head studies the disposition sheet and the completeness of the files. (f) The implementer shall prepare a letter of request for consideration to the relevant technical office. (g) The head of the relevant technical service provides technical considerations based on the results of the field assessment. (h) Section head examines technical considerations, and field review reports. (i) The Back Office officer prepares a draft of the permit/non-license text. (j) Section head examines the draft permit/non-permit. (k) The head of the field checks the draft of the permit/non-license text. (l) The head of the service signs the permit/non-permit document. $(\mathrm{m})$ The executor shall give the number and date of the permit/non-permit text. (n) The applicant receives a permit/non-permit script. (o) The executor documents the permit script. Completion Time: 25 working days from receipt of a complete and correct application by paying levies, if any, in accordance with applicable regulations.

This mining activity can create positive aspects for employment and business opportunities for the community around the activity location and can also contribute to Regional Original Income (PAD) (Mardiasmo 2011).

The contribution of tax revenues from the mining sector is still low, as stated by the Head of the Regional Revenue Management Agency as follows:

"In increasing local revenues from mining taxes, together with relevant agencies, we have made various efforts including field monitoring and using a target system by looking at the potential. However, these efforts have not been able to increase regional income because so far, our officers have experienced many obstacles, including the difficulty of collecting taxes from miners who do not have permits for underground water extraction because, in the Regional 
Government Regulation concerning mining tax collection, as well as Mayor Regulation no. $1384 / 2016$, illegal miners are not allowed to collect taxes/levies before obtaining a permit". (APR, Head of the Regional Revenue Management Agency)

The statement explains that increasing mining tax revenue is difficult, due to lack of awareness to have a permit, awareness to pay it, and the absence of regulations governing mining activities in Bandung City.

In addition, the Head of the Environmental and Hygiene Services (DUP) said:

\begin{abstract}
"Regarding licensing and increasing mining and groundwater tax revenues for formal legal aspects, as well as avoiding irregularities, we have compiled a regulation which one of its contents states that every entrepreneur/community submits a permit. Businesses are required to pay a measurement permit fee and exploration fee. The amount depends on the size of the business and we have drafted this type of business which is expected to be accepted by all partners".
\end{abstract}

To see the level of conformity between the formulation of the organization's mission and objectives with the dynamics of change, as well as anticipation and solutions to change, based on observations, in order to support the implementation of the organization's vision and mission, has proposed a draft regional regulation on groundwater management, general mining, waste management and disposal liquid. All of which are still in the process of being discussed in the DPRD. From the description above, the Department of Environment and Hygiene Services of Bandung City has made various efforts, both through the creation of legal instruments and training for all stakeholders. It is supported by the statement of the Head of Development, Supervision, and Control (LEN): "We realize that the results achieved from the organization's activities are not satisfactory because as a new institution, so far we are still in the process of reforming legal instruments, training, and socialization".

Responsiveness. The Bandung City Environment and Hygiene Services to sensitivity to licensing services, monitoring, and evaluation and reporting (SIPA/AMDAL/UKL/UPL), has programmed coaching and socialization to miners/entrepreneurs. In the interview, an entrepreneur (KAD) stated that "We realize that so far what has been done has not been in accordance with the regulations, but friends say that there are many requirements for licensing and it costs a lot of money. Even if we don't have a permit, we are ready if we are asked to pay taxes. In addition, entrepreneurs must make regular UKL/UPL reports. In this regard, the Head of the Guidance, Supervision, and Control Division (LEN) stated that "The implementation of socialization and guidance for Environmental Management Effort Documents (AMDAL/UKL) and Environmental Monitoring Efforts (UPL) are prepared to prevent, cope with, and control negative impacts that damage nature sustainability and develop its positive impact in accordance with the Regulation of the State Minister of the Environment Number 16 of 2012, concerning Guidelines for the Preparation of Environmental Documents.

From the description above, the licensing flow is still contradictory. The results of an interview with the Section Head of Environmental Development and Supervision (DAR) shows that "We are actually very clumsy in serving Regional Mining Business Permits (SIPD), on the one hand, we have to enforce the rules, on the other hand, we see different activities in the field, so we serve more, prioritize negotiations taking into account the level of community ability, and we really appreciate their good intentions in making the Regional Mining Business Permit (SIPD). The problem in terms of licensing is that we feel that there is no legal instrument regulating this permit for Bandung City, and it still refers to the West Java Provincial Regulation Number 17 of 2001 which does not clearly regulate the types of large and small businesses".

From the statement above, it is clear that the organization's activities in providing services to the community have obstacles in terms of legal instruments as aspects of formal law governing licensing in Bandung City. This can affect the organizational performance of the Environmental and Hygiene Services in carrying out its main tasks and functions because it still uses the West Java provincial 
regulations so that from the responsiveness dimension, it has not been able to respond to interests in Bandung City itself. In the end, it has an impact on the implementation of the program which has not been able to respond to the interests of its citizens, as shown in Table 3.

Table 3.

The miner development program of the plan and realization in Bandung City

\begin{tabular}{lccc}
\hline \multicolumn{1}{c}{ Type of activity } & Plan & Realization & Description \\
\hline $\begin{array}{l}\text { Held socialization on the implementation } \\
\text { of AMDAL UKL, UPL for business } \\
\text { activities }\end{array}$ & 30 companies & $\begin{array}{c}17 \\
\text { companies }\end{array}$ & $\begin{array}{c}\text { For those that } \\
\text { have not been } \\
\text { implemented }\end{array}$ \\
$\begin{array}{l}\text { Held outreach on the management of } \\
\text { natural resources and the environment }\end{array}$ & 50 people & 30 people & \\
$\begin{array}{l}\text { Carry out guidance for reclamation } \\
\text { activities of ex-mining land }\end{array}$ & 4 times & 1 time & \\
\hline \multicolumn{2}{l}{ Source: Bandung City Environmental Management Agency, (processed by researchers) }
\end{tabular}

The Table 3 shows that the awareness-raising program for entrepreneurs/miners was not realized because, in the socialization of the implementation of the Environmental Impact Analysis (AMDAL) and Environmental Monitoring Efforts (UKL and UPL), only 17 companies participated in Environmental Monitoring Efforts. Besides, coaching activities for reclamation can only be done once. A previous study reveals that regular supervision from the government to the field level is an important instrument (Junaenah 2020). Another study states that environmental management is closely related to both human and natural resources (Drakel 2010).

Although various efforts have been made to foster entrepreneurs/miners, some obstacles still occur. The Head of the Environmental Development and Supervision Section (DAR) in the interview explains that:

\begin{abstract}
"After we carried out monitoring in the field, it turned out that many entrepreneurs still did not obey the regulations, such as many unlicensed miners, throwing industrial waste into the river due to environmental pollution of industrial and domestic waste, as well as the lack of compliance by entrepreneurs/industry in Environmental Monitoring Efforts. Therefore, monitoring, evaluation, and reporting are important".
\end{abstract}

Based on the above discussion, it proves that three-dimensional-based supervision (monitoring, evaluation, and reporting) in the organizational performance of the Bandung City Environment and Hygiene Services cannot be separated. It also proves that each aspect has a relationship that affects the organizational performance of the Environmental and Hygiene Service of Bandung City in carrying out its main task to achieve organizational goals.

Accountability. Accountability is essentially about how the Bandung City Environment and Hygiene Services can follow up on the hopes and aspirations of the public and political officials. The more follow-ups, the better the performance accountability. Based on the research results, the accountability of the Department of Environment and Hygiene Services in realizing the policies and aspirations of its citizens has been running even though it has not been optimal. Since the expansion of Bandung City in 1987, the fulfillment of clean water needs by the Regional Drinking Water Company (PDAM) has not been fulfilled. According to PDAM Tirtawening data, Bandung City was only able to serve $72 \%$ $(1,802,670$ people) in 2020, while the national target for drinking water services for big cities was $88 \%$. It shows that PDAM service coverage has not yet reached the national target. Based on observations, one of the triggers is the rise of residents to drill wells. Therefore, it takes coordination and cooperation between PDAM and the Department of Environment and Hygiene Services to improve its performance management. The success of achieving organizational goals cannot be separated from the determination of the service method through the establishment of policies, programs and activities (Andhika 2017). 
The purpose of the establishment of the Department of Environment and Hygiene Services according to the Mayor of Bandung is to organize institutional arrangements and local government management as regulated in the Bandung City Regional Regulation that aims to improve institutions, local government apparatus systems, foster and develop general government so that they are effective and efficient.

It is in with the previous study (Astuti 2010) that efficiency in the local government environment includes activities to rearrange organizational structures, work mechanisms, and adequate laws and regulations to ensure the effectiveness and efficiency of government administration, public service delivery. Another opinion (Yusrianti \& Safitri 2015) states that the functions, organizational structure, qualifications, and quantity of employees, as well as fostering working relationships between government organizations and community organizations, are aimed at improving services to the community. Therefore, the implementation of regional autonomy is expected to improve public services effectively and efficiently.

With regard to improving performance, (Hermawan \& Hutagalung 2019) said that excellent service requires an increase in personnel services and community participation. Meanwhile, for environmental sustainability, (Huruta \& Kurniasari 2018) revealed that water is a basic need of the community. If the needs are not served by the government, then the community will find its own solutions even without permission. The results of another study (Rijal et al. 2013) show that community participation in natural resources and the environment is still low.

The opinion related to the provision of public goods was conveyed by (Keban 2014) that the government has a responsibility for the provision of public goods. This is relevant to the results of interviews with a resident (KAD) in the expansion area in eastern Bandung who have previously lived there. "Together with other residents, we drill underground water for the common good and we manage it independently, which is basically from us by us and for us." Therefore, the performance seen from accountability is closely related to the improvement of apparatus services and the provision of public goods, as well as public participation in increasing their awareness.

\section{The factors that affect organizational performance at the Bandung City Environmental and Sanitation Service}

Factors that affect performance according to (Atmosoeprapto 2002) include external factors (political, economic, and social factors) and internal factors (organizational objectives, organizational structure, human resources, and organizational culture).

The results of this study revealed that two factors influenced the performance of the Department of Environment and Hygiene Services in Bandung City including (1) organizational structure, (2) Human Resources (HR), as shown in Table 4.

Table 4.

Factors influencing the performance of the Bandung City environment and hygiene services

\begin{tabular}{|c|c|c|}
\hline Influential factors & Description & Impact \\
\hline Organizational structure & $\begin{array}{l}\text { With the organizational structure } \\
\text { based on Mayor Regulation Number } \\
1384 \text { of } 2016 \text {, it is clear that there is } \\
\text { no authority in the underground water } \\
\text { sector mining. }\end{array}$ & $\begin{array}{l}\text { Tthas not been able to respond to } \\
\text { the interests of its citizens in the } \\
\text { management of underground } \\
\text { water, so it will be dangerous } \\
\text { with irregular mining, and it is } \\
\text { difficult to obtain permits. }\end{array}$ \\
\hline Human Resources (HR) & $\begin{array}{l}\text { HR competencies do not support tasks } \\
\text { in their fields because the formation } \\
\text { is still lacking and the educational } \\
\text { background is inadequate. }\end{array}$ & $\begin{array}{l}\text { Community services are } \\
\text { hampered so that work is slow } \\
\text { to complete. }\end{array}$ \\
\hline
\end{tabular}

Source: Primary data 
Based on Table 4, the researchers describe (1) organizational structure, (2) human resources in the following sections.

Organizational Structure. One of the factors that affect organizational performance is the delegation of authority. The results of Soetrisno's research (Soetrisno 2010) reveal that the delegation of authority has a significant and positive effect. The results of this study also reveal that the authority that has not been delegated to the mining sector from the West Java Provincial Government to the City of Bandung has an effect on mining services for the underground water sector. Relation to the anticipated workload in the new organization, (Dwiyanto 2012) proposes collaborative, functional, and structural strategies. The results of an interview with the Head of Development, Supervision, and Control (LEN) shows that:

"The organizational structure of the Bandung City Environment and Hygiene Services based on the Bandung Mayor's Decree has not been able to serve the mining sector so that it always involves the West Java Provincial Government, and further develops functional positions".

This statement proves that the existing organizational structure has not been able to serve the mining sector, so collaboration is needed. Based on observations, the organizational structure of the Department of Environment and Hygiene Services has not been able to serve mining and energy affairs, meanwhile, the service is still coordinating with the West Java Provincial Government. The Head of Development, Supervision, and Control (LEN) in the interview stated that:

"To anticipate changes in the organizational structure, functional positions have been prepared, but until now these positions have not been well organized so they are still vacant. In fact, we really need human resources in the mining sector, electricity experts, and environmental experts. To overcome this, we are coordinating with the West Java Provincial Government."

The following Figure 2 is a chart of the organizational structure of the Bandung City Environment and Hygiene Services.

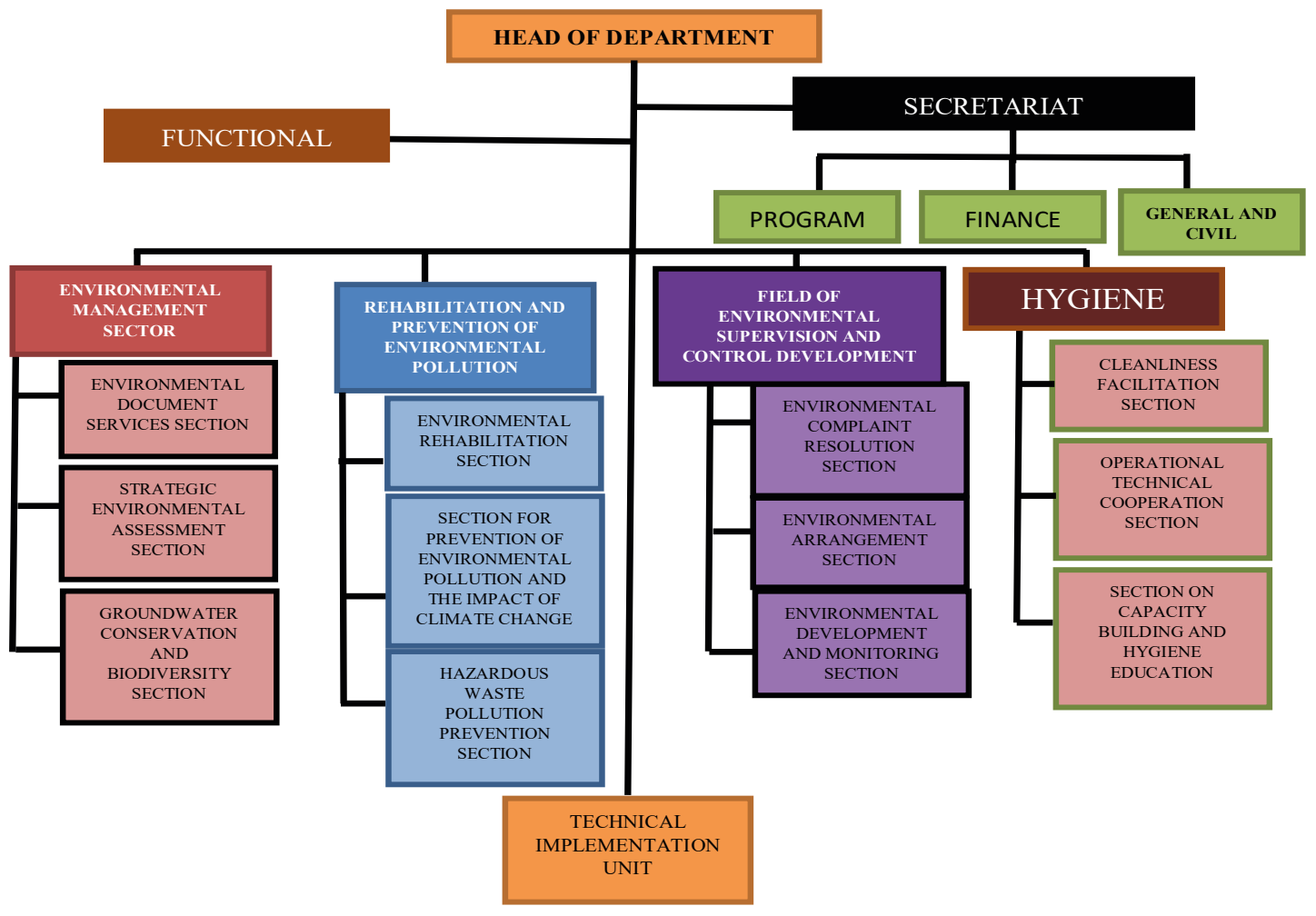

Figure 2.

Chart of the organizational structure of the environment and hygiene services of Bandung City Source: DLHK Kota Bandung (2020) 
Referring to Figure 2, the organizational structure and the main tasks and functions of the Bandung City Environment and Hygiene Services are based on the Bandung City Regional Regulation number 8 of 2016. In practice, however, the organizational performance has not been optimal in line with the issuance of Law No. 23 of 2014 which revoked mining affairs in Indonesia. The underground water sector is under the authority of the provincial government. Related to the work base, (Qodriyatun 2016) states that regulations are the basis for carrying out official duties. Therefore, legal instruments are the most basic foundation needed by the Environmental and Hygiene Service to carry out their main duties and functions.

Judging from the formulation of objectives contained in the description of the main tasks and functions of the Environment and Hygiene Service, there are no clear objectives related to mining and energy. Likewise, the division of tasks and delegation of authority have not yet emerged. Meanwhile, the implementation of coordination is limited to the formation of a coordination team for the licensing process as a means of fostering and supervising the implementation of activities related to the environment. Therefore, the existing structure has consequences on the utilization of employees in accordance with the competencies expected in the organizational structure.

While organizational functions are seen from the level of employee control in carrying out their duties, with the existing organizational structure, the control carried out by the head of the field towards employees will not experience difficulties because the head of the service sector does not directly control. The control is carried out by the Secretary of Service or the head of the field. Then, the Secretary, The Head of Division oversees the section head, or the head of the sub-section is then assigned to the employee or implementer. However, it should be directed to a lean structure but rich in functions, which is developed due to the various functions and organizational specializations required to achieve organizational goals, making the hierarchical level will be minimal and authority decentralized (Herawaty 2014).

In carrying out its main duties and functions, the Department of Environment and Hygiene Services is related to the organizational structure described above. It is clear that the current organizational structure of the Department of Environment and Hygiene Services can influence organizational activities in achieving the mission and goals of the organization, with the principle of "lean function-rich structure" while waiting for the mining authority to be handed over.

Human Resources. In accordance with the workload of the Bandung City Environment and Hygiene Service, with 16 existing structural positions and functional positions that have not been filled, based on the analysis of employee job requirements, 45 human resources with educational background composition are needed. They need to have expertise in geology/mining, environment, electrical engineering, and other disciplines. The Head of Development, Supervision and Control (LEN) in the interview stated that:

\footnotetext{
"As a new field, we still lack human resources both in terms of quantity and quality. If you look at the existing organizational structure with 16 structural positions and the existence of Functional Positions and Officials as well as Branch organizational devices and look at the volume of work assignments, then it takes at least 45 special implementing staff for these services. However, currently, there are only 33 people including structural officials and two contract people. Our difficulty is with the task of monitoring and evaluating activities in the field with a relatively large number of companies while the number of employees is limited. So, we cannot carry out supervision at all times but we do it by means of a periodic system".
}

Based on this, the Department of Environment and Hygiene Services of Bandung City still lacks human resources both in quantity and quality. With an organizational structure that has four levels with 16 structural positions consisting of the head office, one section with three heads of fields each consisting of 3 subsections, and 8 sections, adequate human resources are needed to support the implementation of tasks. 
Running an organization must be supported by competent human resources in accordance with their duties because human resources are one of the sources that affect the performance of public organizations. Head of Environmental Development and Supervision Section (DAR) in an interview stated that:

\begin{abstract}
"In accordance with the duties and authorities of the Environment and Hygiene Service, which are managing the environment, mining, and energy, apparatus with special abilities, for example for mining, government officials, are required. They must master the potential or content of existing mining raw materials and how many years if exploited. And for now, we are coordinating with the West Java Provincial Government."
\end{abstract}

The statement shows that the Department of Environment and Hygiene Services requires employees who have a background in geology/mining, environment, electrical engineering, and other disciplines to carry out the tasks at the department.

Human resources are seen from the competence of employees so that 30 employees at the Bandung City Environment and Hygiene Services generally have experience and have worked with varying lengths of work in previous agencies. Meanwhile, to support the implementation of new duties and functions, employees are included in technical education, both at the district/city level and at the level of West Java Province. The technical education that has been followed to date includes Environmental Impact Analysis (AMDAL) and Environmental Management Plan (RKL), as well as participation in workshops, and other functional technical training.

Based on observations, as explained earlier, after attending training, employees, in general, can carry out tasks in learning by doing. If they experience difficulties, they coordinate with the technical service so that the work can be continued. Therefore, to make the Environment and Hygiene Services successful, human resources are needed that support activities to overcome environmental problems, including mining (Sukarno et al. 2020). Of the existing resources in the organization, human resources play a central and most decisive role. Without reliable human resources, processing, use, and utilization of other resources will not be effective, efficient, and productive (Sedarmayanti 2009).

\title{
The relationship between organizational structure, human resources, and financial variables
} with performance at the environmental and hygiene services

According to Robbins (2003) in (Gammahendra et al. 2014), several dimensional variables of organizational structure include: (a) Administrative components, (b) Autonomy, (c) Centralization, (d) Complexity, (e) Delegation of authority, (f) Differentiation, (g) Formalization, (h) Integration, (i) Professionalization, (j) Span of control, (k) Specialization, (1) Standardization, and (m) Vertical span.

The results show that the dimensional variables of the organizational structure of the delegation of authority by Robbins (2003) in (Gammahendra et al. 2014) have not been implemented. Therefore, it becomes a weakness, among others, the existing structure does not accommodate all the tasks and activities that must be carried out by the department/field, such as those specifically dealing with underground water sector mining, energy, other than functional positions are still vacant and not filled. It is strengthened with the issuance of Law number 23 of 2014 that the authority for mining affairs is withdrawn to the provincial government level (Elvalina et al. 2016). This situation affects the organizational performance of the Bandung City Environment and Hygiene Office.

The performance of the organization as seen from the accountability indicators show that the follow-up to the expectations of the community and the aspirations of political officials did not achieve the stated goals. This means that there are inconsistencies in policies, implementation, and poor community, and environmental conditions. 
Likewise, if it is associated with accountability indicators, with an organizational structure that has not accommodated all activities, it will affect efforts to develop entrepreneurs/miners who violate the rules. This has an impact on the level of mining and groundwater tax revenue which is the authority of the agency. This is also due to the lack of support for educational background competencies that are relevant to the main tasks and functions of the institution. Of the 33 employees at the Department of Environment and Hygiene Services of Bandung City, none of them have a formal educational background in mining and electrical engineering, even though the agency in addition to managing the environment also manages mining and energy. The linkage of funding sources (finance) with indicators of accountability, responsibility, and responsiveness shows that to carry out guidance, monitoring, and evaluation of environmental and mining management activities, funding sources are needed. Likewise, reclamation of ex-mining land requires funds.

The results of the study reveal that the lack of budgetary support for mobility, facilities, and infrastructure has resulted in negative impacts on the environment that have not been resolved, such as pollution, low income from the underground water sector mining, mining practices that ignore permits, and many companies that do not have required documents. Environmental Impact Analysis, Environmental Management Efforts, and Environmental Monitoring Efforts do not provide environmental management and monitoring reports.

\section{Conclusion}

The results of the study show that the performance of the Environmental and Hygiene Services is not optimal because regarding (a) responsibility, the policy of the service has not been able to fulfill services in the underground water sector mining sector because the legislation is still inadequate (b) responsiveness, the service has not fully responded to the needs of the community, develop service agendas and priorities, and develop public service programs in accordance with the needs and aspirations of the community, and (c) accountability, that has not been able to meet the service demands of the community's needs in the underground water sector properly.

Factors that affect organizational performance at the Bandung City Environment and Hygiene Services include (1) organizational structure, that has not been able to respond to the demands of community service needs effectively and efficiently. The services flow becomes long because underground water services are the authority of the government province, (2) human resources, HR competencies do not support tasks in their fields due to lack of formation and inadequate educational background so that public services are hampered and slow to complete. The researchers suggest that innovation management strategies and policy communication with other regional, provincial, and central governments, as well as operational techniques, need consistent enforcement of regulations, and collaboration pentha-helix, both by involving academics (universities), business (the business world), government (between government and partners), media (print/electronic), and the community as the recipient of bureaucratic services.

\section{References}

Ahyaruddin M \& Akbar R (2018) Indonesian local government's accountability and performance: The isomorphism institutional perspective. Journal of Accounting and Investment 19 (1):1-11. https:// doi.org/10.18196/jai.190187.

Akmaludin M \& Yuniati (2019) Analysis of community purchasing ability of clean water tariffs (PDAM) Kota Bandung using contingent valuation method (CVM). Jurnal Teknik Lingkungan 25 (1):29-42.

Andhika LR (2017) Evolusi konsep tata kelola pemerintah: Sound governance, dynamic governance dan open government. Jurnal Ekonomi \& Kebijakan Publik 8 (2):87-102. https://doi.org/10.22212/ jekp.v8i2.867.

Astriani N (2016) Legal policy of water resources management by local governments: A review of right to water in Indonesia. Hasanuddin Law Review 2 (2):250-257. http://dx.doi.org/10.20956/halrev. v1i2.309. 
Astuti SJW (2010) Akuntabilitas diskresi birokrasi di era otonomi daerah. Masyarakat, Kebudayaan Dan Politik 23 (2):85-94.

Atmosoeprapto K (2002) Menuju SDM Berdaya - Dengan Kepemimpinan Efektif dan Manajemen Efisien. Jakarta: PT. Elex Media Komputindo.

Behn RD (2003) Why measure performance? Different purposes require different measures. Public Administration Review 63 (5):586-606. https://doi.org/10.1111/1540-6210.00322.

Dinas ESDM Kota Bandung (2020) Evaluasi Kondisi Air Tanah di Cekungan Bandung. Bandung: Pemprov.

DLHK Kota Bandung (2020) LAKIP Dinas Lingkungan Hidup dan Kebersihan Kota Bandung. Bandung: Pemerintah Kota Bandung.

Drakel A (2010) Kebijakan pengelolaan lingkungan hidup berbasis ekonomi sumberdaya di Propinsi Maluku Utara. Jurnal Agribisnis Perikanan 3 (1):90-100. https://doi.org/10.29239/j. agrikan.3.1.90-100.

Dwiyanto A (2012) Manajemen Pelayanan Publik: Peduli, Inklusif, dan Kolaboratif. Yogyakarta: Gadjah Mada University Press.

Elvalina D, Firdaus E, \& Edorita W (2016) Kewenangan pemerintah daerah provinsi dalam menerbitkan izin pertambangan berdasarkan Undang-undang Nomor 23 Tahun 2014 tentang Pemerintahan Daerah. JOM: Fakultas Hukum Universitas Riau 3 (2):1-15.

Gammahendra F, Hamid D, \& Riza MF (2014) Pengaruh struktur organisasi terhadap efektivitas organisasi (studi pada persepsi pegawai tetap kantor perwakilan Bank Indonesia Kediri). Jurnal Administrasi Bisnis (JAB) 7 (2):1-10.

Herawaty N (2014) Faktor-faktor yang mempengaruhi akuntabilitas kinerja instansi Pemerintah Daerah Kota Jambi. Jurnal Cakrawala Akuntansi 6 (2):151-161.

Hermawan D \& Hutagalung SS (2019) Development of community participation based on behaviour in managing participative programs. Masyarakat, Kebudayaan dan Politik 32 (3):311-322. http:// dx.doi.org/10.20473/mkp.V32I32019.312-322.

Huruta AD \& Kurniasari MD (2018) Environmental management within the indigenous perspective. Masyarakat, Kebudayaan dan Politik 31 (3):270-277.

Junaenah I (2020) Supervision on by-law of local government in Indonesia: Lesson fromrefreshed central-local relationship in New Zealand. Jurnal Ilmu Hukum 16 (2):160-176. https://doi. org/10.30996/dih.v16i2.3372.

Keban YT (2014) Enam Dimensi Strategi Administrasi Publik: Konsep, Teori dan Isu. Yogyakarta: Gava Media.

Kelly JM \& Swindell D (2002) A multiple-indicator approach to municipal service evaluation: Correlating performance measurement and citizen satisfaction across jurisdictions. Public Administration Review 62 (5):610-621. https://doi.org/10.1111/1540-6210.00241.

Mardiasmo (2011) Peningkatan pendapatan asli daerah. Makalah Seminar Otonomi Daearah. Batam: Ikatan Sarjana Ekonomi Indonesia (ISEI).

Muis I, Ismail, Erlangga H, \& Engkus (2019) Post disaster social vulnerability: Policy analysis and implementation in communities in Indonesia. Journal of Critical Reviews 6 (5):59-65.

Nugroho W, Imamulhadi, Nugroho BD, \& Nurlinda I (2019) Kebijakan pengelolaan tambang dan masyarakat hukum adat yang berkeadilan ekologis. Jurnal Konstitusi 15 (4):816-835. https://doi. org/10.31078/jk1547.

Permana D (2017) Reformasi administrasi izin pengambilan dan pemanfaatan air bawah tanah pada BPM PT Provinsi Jawa Barat (studi kasus pengambilan dan pemanfaatan air bawah tanah di Kota Bandung). Disertasi, Universitas Padjadjaran, Bandung.

Pollitt C \& Bouckaert G (2011) Public Management Reform: A Comparative Analysis - New Public Management, Governance, and the Neo-Weberian State (Third). Oxford: Oxford University Press.

Qodriyatun SN (2016) Konservasi sumber daya alam hayati dan ekosistemnya dalam kerangka desentralisasi. Kajian 15 (3):551-577. https://doi.org/10.22212/kajian.v15i3.582.

Rijal F, Madani M, \& Fatmawati (2013) Interaksi aktor dalam perumusan kebijakan pengelolaan pertambangan di Kabupaten Kolaka Utara. Otoritas: Jurnal Ilmu Pemerintahan 3 (2):19-36. 
Sumual TEM (2017) Manajemen Sumber Daya Manusia. Edisi Revisi. Surabaya: CV. R.A.De.Rozarie. Sedarmayanti (2009) Sumber Daya Manusia dan Produktivitas Kerja. Bandung: CV Mandar Maju.

Soetrisno (2010) Pengaruh partisipasi, motivasi, dan pelimpahan wewenang dalam penyusunan anggaran terhadap kinerja manajerial (Studi empiris pada Dinas Daerah dan Lembaga Teknis Daerah di Kabupaten Rembang). Thesis, Universitas Diponegoro, Semarang.

Sukarno SA, Tinangon JJ, \& Tangkuman SJ (2020) Pengaruh kompetensi aparat dan komitmen organisasi terhadap implementansi sistem akuntabilitas kinerja instansi pemerintah (studi pada Kantor Perwakilan Badan Pengawasan Keuangan dan Pembangunan Provinsi Sulawesi Utara). Indonesia Accounting Journal 2 (2):110-117. https://doi.org/10.32400/iaj.27981.

Suwaryo U (2006) Implementasi kebijakan otonomi daerah (studi kasus tentang kewenangan dalam aplikasi otonomi daerah berdasarkan Undang-Undang Nomor 22 Tahun 1999 di Kabupaten Bandung). Sosiohumaniora 8 (3):255-271. https://doi.org/10.24198/sosiohumaniora.v8i3.5558.

Tangkilisan HNS (2007) Manajemen Publik. Jakarta: Grasindo.

Yusrianti H \& Safitri RH (2015) Implementasi sistem akuntabilitas kinerja instansi pemerintah (SAKIP) pada satuan kerja perangkat daerah (SKPD) di lingkungan pemerintah Kota Palembang. Jurnal Manajemen dan Bisnis Sriwijaya 13 (4):545-558. https://doi.org/10.29259/jmbs.v13i4.3153. 